\title{
INFLUENCE OF VANADIUM AND CHROMIUM ADDITION ON MORPHOLOGY AND COMPOSITION OF IRON BASED PHASES IN AlSi10MgMn ALLOY
}

\begin{abstract}
Application of secondary Al-Si alloys is mostly influenced by amount of impurities. Detrimental effect of iron, as the most harmful impurity, refers mainly to morphology of iron intermetallic phases. Morphology of iron phases can be influenced by several methods from which the most common is addition of some elements. In primary alloys manganese is commonly used, but its influence is not such favourable in high iron levels because of so-called sludge phase formation. Higher iron content thus requires other alloying elements which can be vanadium, chromium or others. In this article, vanadium and mutual vanadium and chromium influence on iron phase morphology and chemical composition is analysed by optical microscopy, SEM observations and EDX analysis.
\end{abstract}

Keywords: AlSi 10MgMn alloy, iron based intermetallic phase, vanadium, chromium.

\section{Introduction}

In recent years much effort is being expended to protect the earth's environment and one of the most desirable concepts that have been established through these developments is the recycling of waste materials. Aluminium waste must be one of the most desirable materials for recycling or re-using. This is because the energy costs involved in its production can be reduced by up to $95 \%$ by recycling $\mathrm{Al}$ scrap, as the production of $\mathrm{Al}$ from its ore, bauxite, is an energy consuming and very expensive process [1]. However, the increasing use of recycled aluminium casting alloys warrants strict process control to remove the ill effects of impurity elements [2]. From impurity elements, the most harmful is thought to be iron [3 - 5].

Presence of iron in $\mathrm{Al}-\mathrm{Si}$ cast alloys is a common problem in primary alloys but it becomes more important in secondary (recycled) aluminium alloys made from scrap materials. The reason why iron has such detrimental influence is that although iron is highly soluble in liquid aluminium and its alloys, it has very little solubility in the solid (max. 0.05 wt. \%) and so it tends to combine with other elements to form intermetallic phase particles of various types [5]. Intermetallic phases present in the alloys then decrease mechanical properties of the alloy and also porosity of final casting can be increased by iron phases.

A variety of Fe-rich intermetallic phases have been observed in aluminium alloys. In Al-Si-Fe system there are five main Fe-rich phases: $\mathrm{Al}_{3} \mathrm{Fe}$ (or $\mathrm{Al}_{13} \mathrm{Fe}_{4}$ ), $\alpha-\mathrm{Al}_{8} \mathrm{Fe}_{2} \mathrm{Si}$ (possibly $\alpha-\mathrm{Al}_{12} \mathrm{Fe}_{3} \mathrm{Si}_{2}$ ), $\beta-\mathrm{Al}_{5} \mathrm{FeSi}, \delta-\mathrm{Al}_{4} \mathrm{FeSi}_{2}$ and $\gamma-\mathrm{Al}_{3} \mathrm{FeSi}$ [6]. The most common intermetallic phase is $\beta$ - $\mathrm{Al}_{5} \mathrm{FeSi}$ that is also considered to have the most detrimental effect on mechanical and foundry properties of Al-Si type alloys. The platelet-like morphology of the $\mathrm{Al}_{5} \mathrm{FeSi}$ phase allows it to act as a stress raiser, consequently undermining the mechanical properties of the cast part, mainly tensile strength and elongation [5]. As the fraction of insoluble phase increases with increased iron content, casting properties such as fluidity and feeding characteristics are also adversely affected. Iron also lead to the formation of excessive shrinkage porosity defects in castings [7]. If $\mathrm{Mg}$ is present with $\mathrm{Si}$, an alternative phase can form, $\pi-\mathrm{Al}_{8} \mathrm{Fe} \mathrm{Mg}_{3} \mathrm{Si}_{6}$ [5]. Phase $\pi-\mathrm{Al}_{8} \mathrm{FeMg}_{3} \mathrm{Si}_{6}$ occurs in script-like morphology and it has a negative impact on ductile properties of Al-Si-Mg alloys [8]. For the more usual Al-Si-Mg cast alloys of modest $\mathrm{Mn}$ contents, the $\mathrm{Al}_{15}(\mathrm{Fe}, \mathrm{Mn})_{3} \mathrm{Si}_{2}$ phase often has an appearance of Chinese script in section, being irregular or convoluted. If $\mathrm{Fe}$ and $\mathrm{Mn}$ are sufficiently high, primary $\mathrm{Al}_{15}(\mathrm{Fe}, \mathrm{Mn})_{3} \mathrm{Si}_{2}$ phase may appear as hexagonal, star-like, or dendritic crystals.

There is still only little information about vanadium influence on iron-based intermetallic phases in aluminium alloys. In the cast 99.5 Al alloy V addition in amount of 0.1 wt. \% exhibits more cubic $\alpha$-AlFeSi phase than in V-free version in both the as-cast and homogenised conditions, although the effect became more pronounced after homogenisation [9]. Vanadium addition (0.2

\footnotetext{
* ${ }^{1}$ Maria Zihalova, ${ }^{1}$ Dana Bolibruchova, ${ }^{2}$ Dalibor Vojtech

${ }^{1}$ Department of Technological Engineering, Faculty of Mechanical Engineering, University of Zilina, Slovakia

${ }^{2}$ Institute of Chemical Technology, Department of Metals and Corrosion Engineering, Faculty of Chemical Technology, Prague, Czech Republic

E-mail: maria.zihalova@fstroj.uniza.sk
} 
wt. \%) in Al-Si cast alloys containing $3.0 \div 12.0$ wt. \% of Si, $0 \div$ 0.4 wt. \% of $\mathrm{Mg}$ and $0.3 \div 2.3$ wt. \% of Fe have also a beneficial influence on length of $\beta-\mathrm{Al}_{5} \mathrm{FeSi}$ but there was a negligible amount of $\mathrm{V}$ detected in platelets [10]. Previous work [11] shows also a beneficial influence of $\mathrm{V}$ addition on microstructure and mechanical properties of AlSi6Cu4 alloy but vanadium was not detected in iron intermetallic phases at all.

It has been reported that $\mathrm{Cr}$ addition can have similar effect on iron intermetallics as Mn [12]. Chromium improves aluminium alloys strength at indoor and higher temperatures (precipitation of intermetallic compositions of $\mathrm{Cr}$ inhibits the growth of grains) and mildly deteriorates elongation. But the presence of $\mathrm{Cr}$ phases $\mathrm{Al}_{13}(\mathrm{CrFe})_{4} \mathrm{Si}_{4}$ and $\mathrm{Al}_{2}(\mathrm{CrFe})_{5} \mathrm{Si}_{8}$ can increase brittleness [10]. $\mathrm{Cr}$ addition leads to improvement of mechanical properties of as-cast $\mathrm{AlSi} 7 \mathrm{Mg} 0.3$ alloy while the maximal value of tensile strength and elongation was measured at $1.0 \mathrm{wt}$ \% of $\mathrm{Cr}[13-16]$.

There is no available information about the mutual $\mathrm{V}$ and $\mathrm{Cr}$ influence in Al-Si alloy. In the article, vanadium and mutual $\mathrm{V}$ and $\mathrm{Cr}$ influence on iron based intermetallics is analysed in AlSi10MgMn cast alloy by optical microscopy, SEM observations and EDX analysis.

\section{Materials and methodology}

Commercial AlSi10MgMn alloy was used to perform the experiments. Selected alloy was in the first step of experiments polluted by iron by addition of AlFe 10 master alloy. Alloy with 0.98 wt. \% of iron was obtained this way (marked as AlSi10MgMnFe1). Vanadium was added to such prepared secondary alloy in amount of 0.2 wt. \% of V. Combined V and $\mathrm{Cr}$ influence was evaluated on the alloy prepared by chromium addition to vanadium treated alloy in the amount of 0.5 and $1.0 \mathrm{wt}$. \% of Cr. Required amounts of $\mathrm{V}$ and $\mathrm{Cr}$ were added in the form of $\mathrm{AlV} 10$ and $\mathrm{AlCr} 20$ master alloys. The melts were not purified, modified or grain refined. Prepared melts were after reaching pouring temperature $\left(760{ }^{\circ} \mathrm{C}\right)$ poured into a permanent mould preheated to $200{ }^{\circ} \mathrm{C}$. Chemical composition of the alloys is shown in Table 1. Accurate values of $\mathrm{Cr}$ level in alloys with added $\mathrm{V}$ and $\mathrm{Cr}$ could not be measured due to uncommonly high $\mathrm{Cr}$ addition that is out of range of the used spectrometer.

Samples for metallographic observations were prepared from the castings by standard procedure containing cutting, grinding, polishing and etching. Chemical composition of selected intermetallic particles was analysed by EDX analysis.

\section{Results}

Typical microstructure of AlSi10MgMn1 alloy is shown in Fig. 1. As the alloy was not modified, eutectic silicon is present in the form of platelet particles surrounded by aluminium dendrites. Significant amount of iron based intermetallics is also present in the microstructure, mostly in the form of thick needles. Position of the iron phases seems to be preferentially along the eutectic Si. Chemical analysis of the needle-like particle (Fig. 2) shows mainly the presence of $\mathrm{Al}, \mathrm{Si}$ and $\mathrm{Fe}$, but low amount of $\mathrm{Mn}$ was detected as well. Generally, it can be described as $\beta-\mathrm{AlSiFe}$, probably $\mathrm{Al}_{5} \mathrm{FeSi}$.

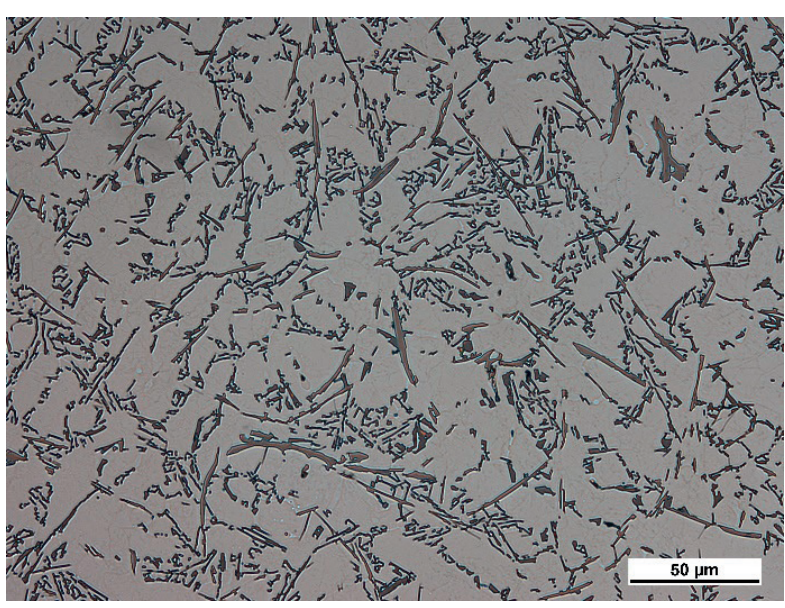

Fig. 1 Typical microstructure of AlSil0MgMnFel alloy, etch. $0.5 \% \mathrm{HF}$

Vanadium addition in amount of 0.2 wt. \% leads to the formation of increased amount of script-like iron phases, but platelets were still in higher number. As it can be seen in Fig. 3, vanadium caused increasing of needle-like particles compared to $\mathrm{AlSi} 10 \mathrm{MgMnFe} 1$ alloy but thickness was decreased. EDX analysis showed the presence of small $\mathrm{V}$ amount in script-like particles (Fig. 4).

Chemical compositions of prepared alloys in wt. \%

Table 1

\begin{tabular}{|l|c|c|c|c|c|c|c|c|c|c|}
\hline Alloy & $\mathbf{S i}$ & $\mathbf{M g}$ & $\mathbf{M n}$ & $\mathbf{F e}$ & $\mathbf{T i}$ & $\mathbf{Z n}$ & $\mathbf{C u}$ & $\mathbf{V}$ & $\mathbf{C r}$ & $\mathbf{A l}$ \\
\hline AlSi10MgMn & 10.220 & 0.277 & 0.108 & 0.448 & 0.046 & 0.029 & 0.047 & 0.010 & 0.006 & rest \\
\hline AlSi10MgMnFe1 & 9.73 & 0.313 & 0.118 & 0.980 & 0.041 & 0.026 & 0.048 & 0.009 & 0.037 & rest \\
\hline AlSi10MgMnFe1 + $\mathbf{0 . 2}$ wt. \% V & 9.133 & 0.265 & 0.116 & 1.588 & 0.034 & 0.026 & 0.046 & 0.216 & 0.166 & rest \\
\hline AlSi10MgMnFe1 + 0.2 wt. \% V + 1.0 wt. \% Cr & 8.996 & 0.291 & 0.119 & 1.446 & 0.033 & 0.029 & 0.047 & 0.139 & $>0.480$ & rest \\
\hline AlSi10MgMnFe1 + $\mathbf{0 . 2}$ wt. \% V + 0.5 wt. \% Cr & 8.539 & 0.290 & 0.098 & 1.182 & 0.031 & 0.028 & 0.053 & 0.135 & $>0.480$ & rest \\
\hline
\end{tabular}




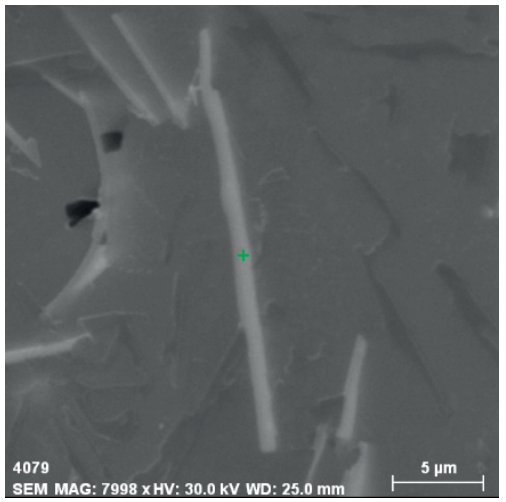

a)

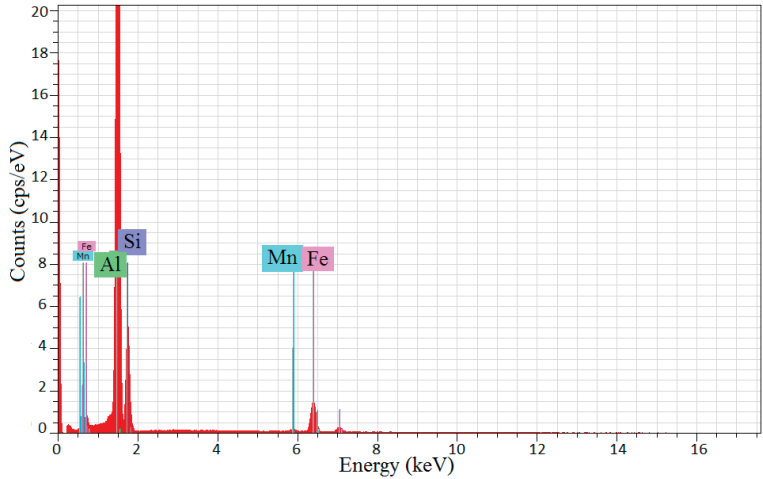

b)

Fig. 2 EDX analysis of needle-like phase in AlSi10MgMnFe1 alloy: a) SEM image of analysed place, b) EDX spectrum

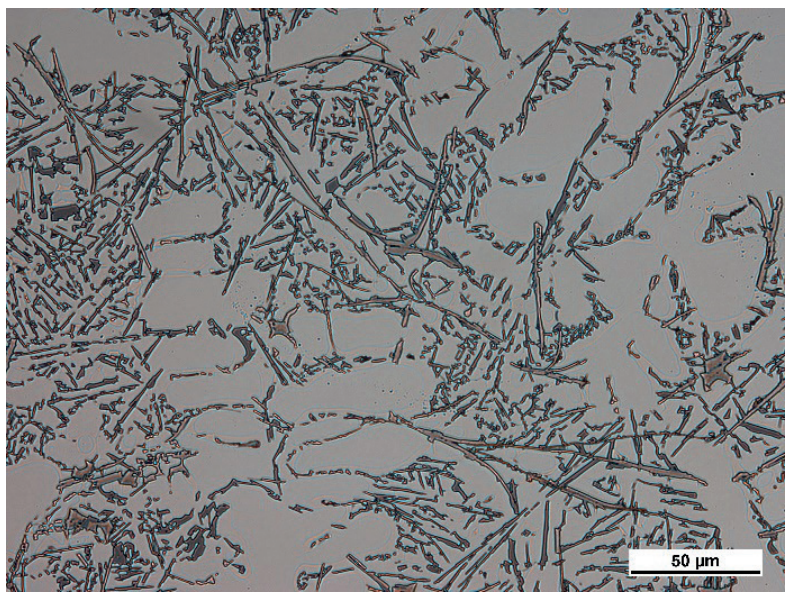

Fig. 3 Typical microstructure of AlSilOMgMnFel alloy with 0.2 wt. \% of $\mathrm{V}$, etch. $0.5 \% \mathrm{HF}$

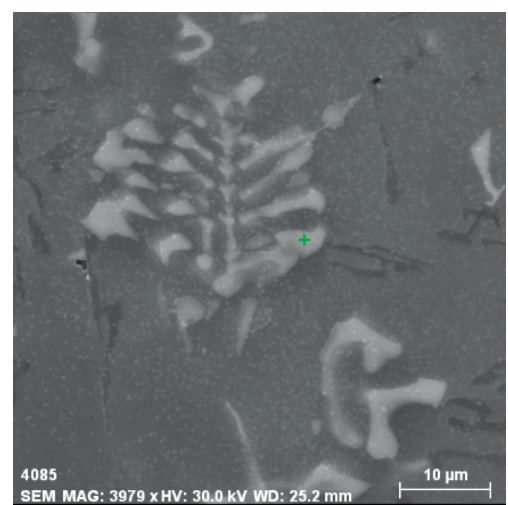

a)

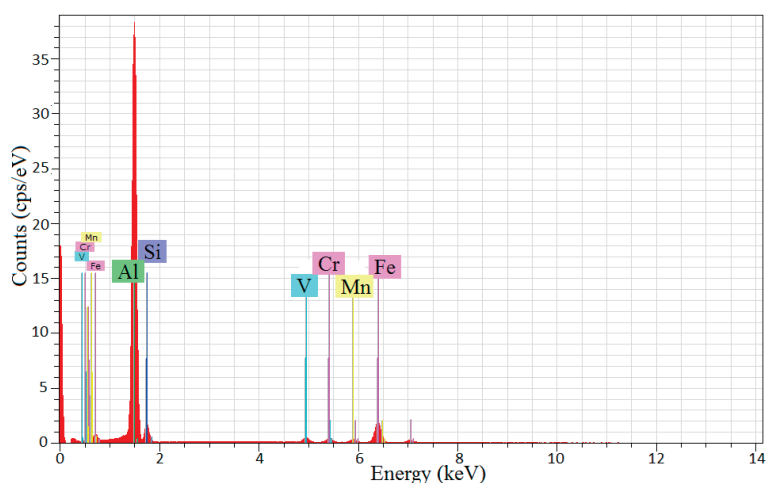

b)

Fig. 4 EDX analysis of script-like phase in AlSilOMgMnFe1 alloy with 0.2 wt. \% of V: a) SEM image of analysed place, b) EDX spectrum

Mutual $\mathrm{V}$ and $\mathrm{Cr}$ addition leads to the formation of so called "sludge phases". Amount of sludge phases increased with $\mathrm{Cr}$ addition, lower amount was present after addition of $0.5 \mathrm{wt} . \%$ of $\mathrm{Cr}$ (Fig. 5) and higher in the alloy with 1.0 wt. \% of $\mathrm{Cr}$ (Fig. 6). Size and amount of needle-like particle was after the $\mathrm{V}$ and $\mathrm{Cr}$ addition decreased but the formation of sludge phases is thought to be even more deleterious compared to needles or script-like particles. This is due to its high melting point, high specific gravity and hardness which causes the increasing wear of melting devices and deteriorating of the alloy machinability [14]. Except of this, 
once the sludge phase is formed, it cannot be removed from alloy by further re-melting or refining process. Chemical composition of script-like phase present in alloy with $0.5 \mathrm{wt}$ \% $\mathrm{Cr}$ addition shows presence of both $\mathrm{V}$ and $\mathrm{Cr}$ in analysed place (Fig. 7) while

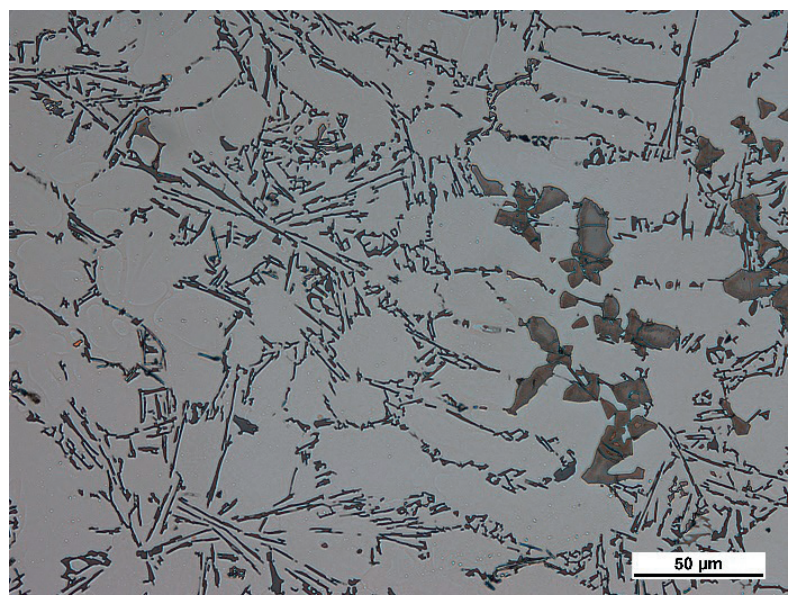

Fig. 5 Typical microstructure of AlSi10MgMnFel alloy with $0.2 \mathrm{wt} . \%$ of $\mathrm{V}$ and $0.5 \mathrm{wt} . \%$ of $\mathrm{Cr}$, etch. $0.5 \% \mathrm{HF}$

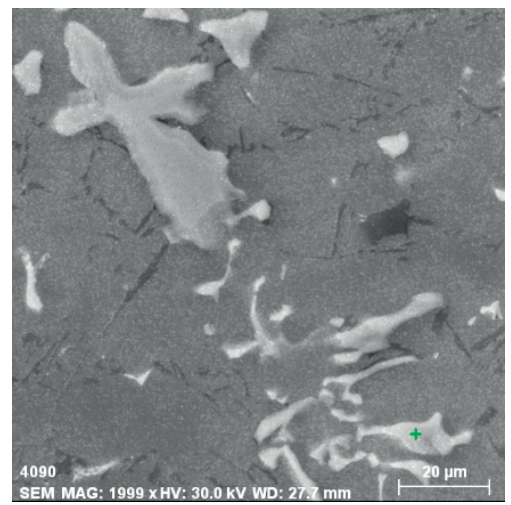

a) in alloy with 1.0 wt. \% of Cr only chromium was detected (Fig. 8). Moreover, the amount of $\mathrm{Cr}$ was lower in a script-like phase after higher chromium addition.

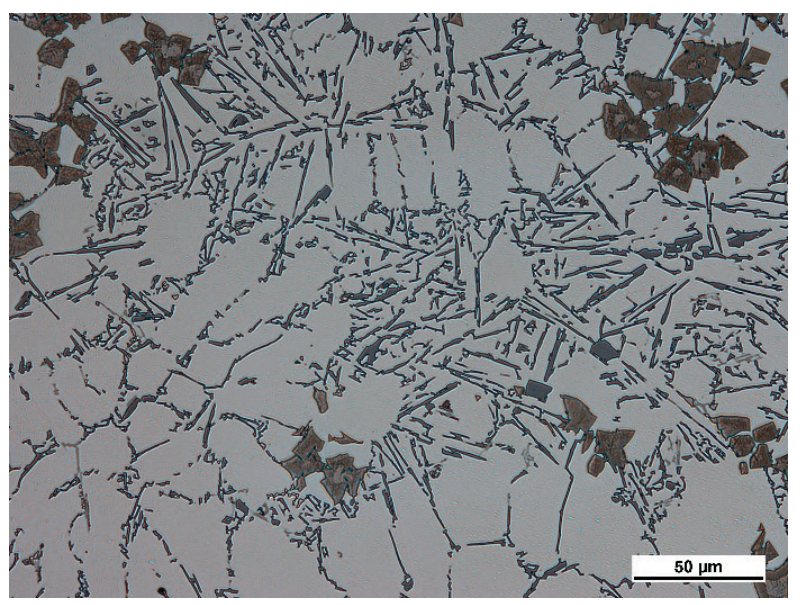

Fig. 6 Typical microstructure of AlSi10MgMnFel alloy with $0.2 \mathrm{wt}$. \% of $\mathrm{V}$ and $1.0 \mathrm{wt} . \%$ of $\mathrm{Cr}$, etch. $0.5 \% \mathrm{HF}$

Fig. 7 EDX analysis of script-like phase in AlSilOMgMnFel alloy with 0.2 wt. \% of V and 0.5 wt. \% of Cr: a) SEM image of analysed place, b) EDX spectrum

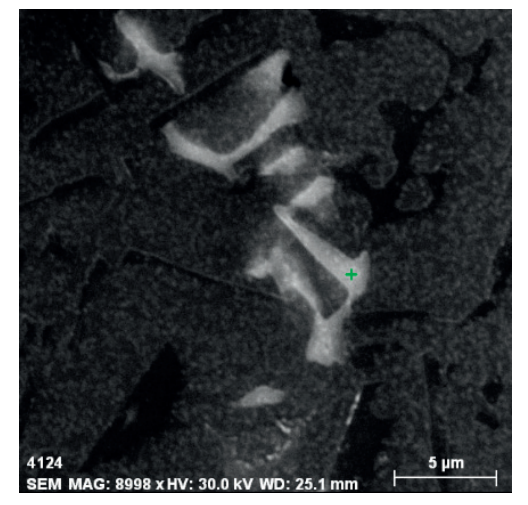

a)

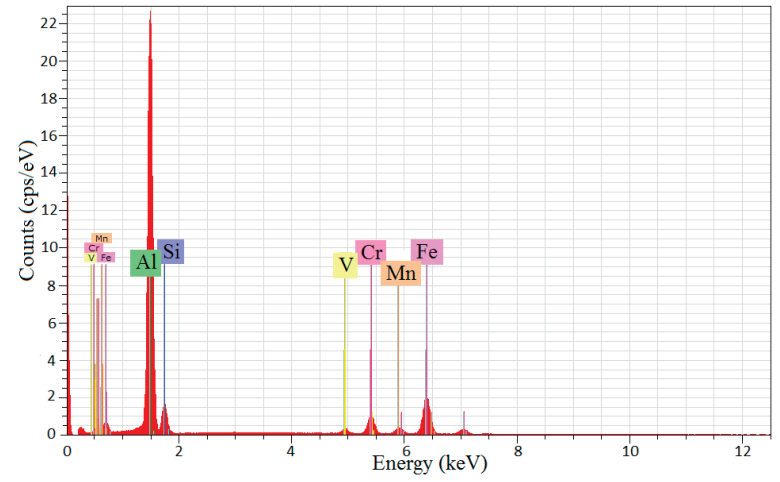

b)

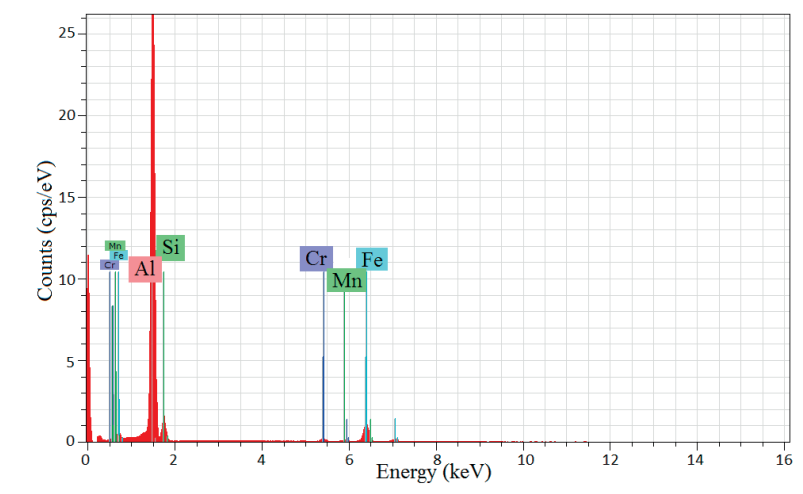

b)

Fig. 8 EDX analysis of script-like phase in AlSilOMgMnFel alloy with 0.2 wt. \% of $V$ and 1.0 wt. \% of Cr: a) SEM image of analysed place, b) EDX spectrum 


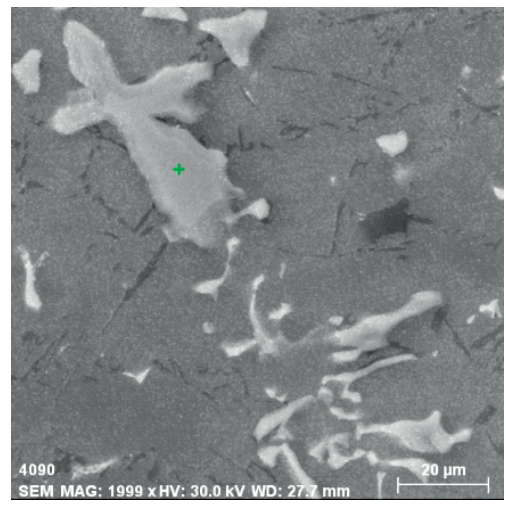

a)

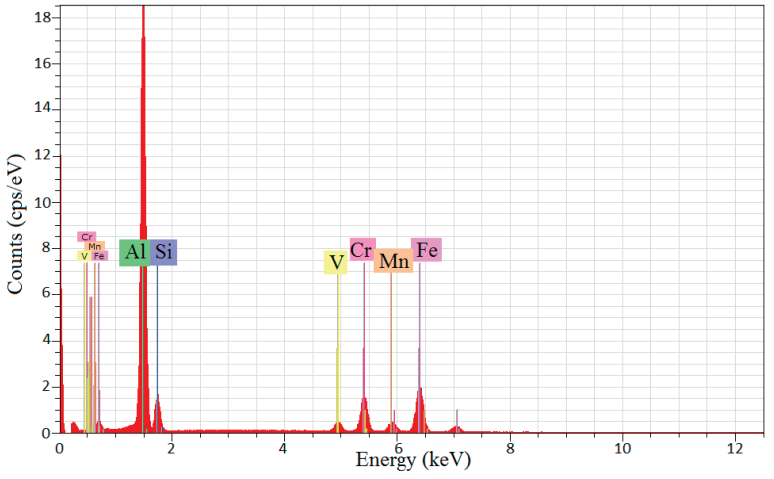

b)

Fig. 9 EDX analysis of sludge phase in AlSilOMgMnFel alloy with $0.2 \mathrm{wt}$. \% of V and $0.5 \mathrm{wt} . \%$ of Cr: a) SEM image of analysed place, b) EDX spectrum

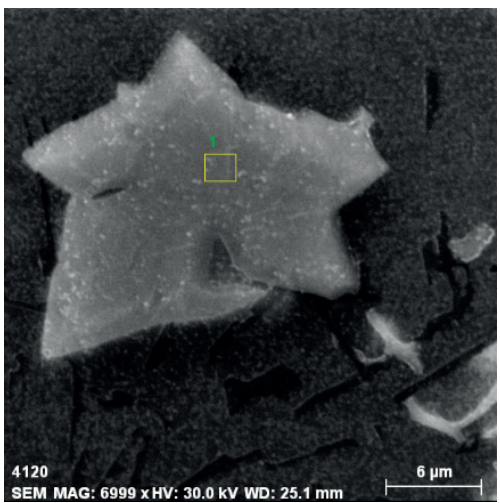

a)

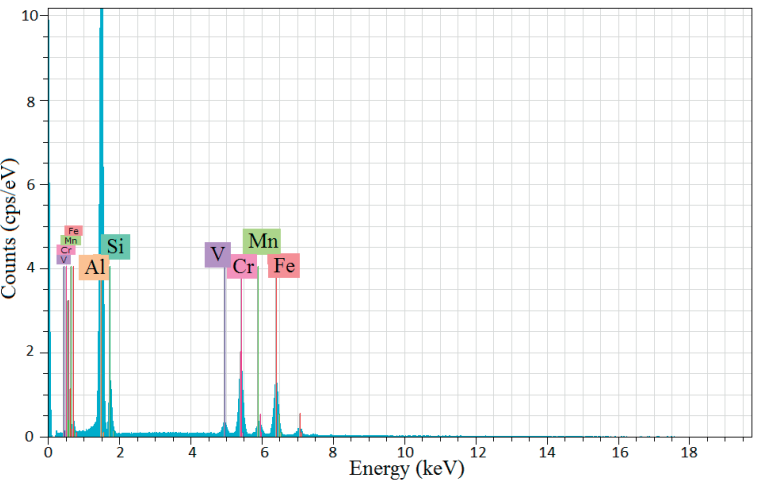

b)

Fig. 10 EDX analysis of sludge phase in AlSilOMgMnFel alloy with $0.2 \mathrm{wt} . \%$ of $V$ and $1.0 \mathrm{wt} . \%$ of Cr: a) SEM image of analysed place, b) EDX spectrum

Sludge phase chemical observations in both $\mathrm{Cr}$ treated alloys (Fig. 9 and 10) show presence of $\mathrm{Al}, \mathrm{Si}, \mathrm{Fe}, \mathrm{Cr}, \mathrm{Mn}$ and $\mathrm{V}$. Amount of $\mathrm{Cr}$ in sludge phase seems to be higher with increasing Cr addition.

\section{Discussion}

Iron addition in the amount of 0.98 wt. \% in AlSi10MgMn alloy leads to formation of thick needle like intermetallic phases $\beta$-AlFeSi. Manganese neutralisation effect on iron in such alloy composition is then insufficient because the $\mathrm{Mn}$ to Fe ratio is only 0.12 (recommended value 0.5 [5, 7 and 14]). Vanadium influence as the iron corrector was analysed in addition of 0.2 wt. \% V. Formation of higher amount of script-like phases was observed. Vanadium also caused change of the needle-like length and thickness. Length of the phases rises in disagreement with the literature [10 and 11], but thickness was reduced. Some needle-like phases have a curved shape (Fig. 3) what might be probably the result of the accidental mechanical hindrance to the straightening action which was observed by other authors [7] and it might be a sign of higher strength of these phases against the loading. Vanadium presence was detected in script-like phases together with $\mathrm{Al}, \mathrm{Si}, \mathrm{Fe}, \mathrm{Mn}$ and $\mathrm{Cr}$. Number of needle-like particles rapidly decreased after mutual $\mathrm{V}$ and $\mathrm{Cr}$ addition but a high amount of sludge phases were observed. The formation of this kind of particles had been observed by many authors [11, 13 and 14] and it is thought to be detrimental to mechanical, foundry properties and machinability of the alloy [14]. Influence of sludge phases on mechanical properties of Al-Si-Mg alloys is still not clear and in spite of the presence of sludge phases in $\mathrm{AlSi} 7 \mathrm{Mg} 0.3$ alloy the tensile properties can increase as it has been shown in [13]. EDX analysis in alloys shows decreasing of $\mathrm{V}$ level present in script-like phases with alloys after $\mathrm{Cr}$ addition. Vanadium and also chromium level rises in the sludge phases with increasing of the $\mathrm{Cr}$ addition. It is possible that not only $\mathrm{Cr}, \mathrm{Mn}$ and $\mathrm{Fe}$ are sludge forming elements, but also $\mathrm{V}$ belongs to that group at its higher levels. 


\section{Conclusions}

Influence of $\mathrm{V}$ and mutual $\mathrm{V}$ and $\mathrm{Cr}$ addition in $\mathrm{AlSi} 10 \mathrm{MgMn}$ alloy were analysed by optical microscopy, SEM observations and EDX analysis. Following conclusions can be drawn from the results:

(1) Detrimental iron effect in the AlSi10MgMn alloy leads to formation of thick platelets of $\mathrm{AlSiFe}$ (probably $\mathrm{Al}_{5} \mathrm{FeSi}$ ) phase placed mainly near the eutectic Si.

(2) Vanadium has an influence on the formation of higher amount of script-like phases and it acts like an iron corrector.
Also thickness of the needle-like particles was reduced by $\mathrm{V}$ addition but the length of needles increased.

(3) $\mathrm{Cr}$ in amount of 0.5 and $1.0 \mathrm{wt}$. \% leads to the formation of sludge phases which might deteriorate mechanical properties of alloy. More sludge phases formed at higher Cr level.

(4) Sludge phases also contain certain amount of $\mathrm{V}$ that might be also a sludge formation element when the content of $\mathrm{Fe}, \mathrm{Mn}$ and $\mathrm{Cr}$ exceeds a critical value.

(5) Vanadium addition in amount of $0.2 \mathrm{wt}$. \% has the most beneficial effect on morphology and chemical composition of iron intermetallics.

\section{References}

[1] YAMAGIWA, K., WATANABE, Y, FUKUI, Y, KAPRANOS, P.: Novel Recycling System of Aluminum and Iron Wastes -in-situ $\mathrm{Al}_{3} \mathrm{Al}_{3} \mathrm{Fe}$ Functionally Graded Material Manufactured by a Centrifugal Method, Materials Transactions, vol. 44, No. 12, 2003 , 2461 2467, ISSN 1347-5320.

[2] SREEJA KUMARI, S.S, PILlAI, R. M., RAJAN, T. P. D., PAI, B. C.: Effects of Individual and Combined Additions of Be, Mn, $\mathrm{Ca}$ and $\mathrm{Sr}$ on the Solidification behaviour, Structure and Mechanical Properties of Al-7Si-0.3Mg-0.8Fe Alloy. Materials Science and Engineering A, vol. 460-461, 2007, 561-573, ISSN 0921-5093.

[3] HURTAlOVA, L., TILlOVA, E., CHALUPOVA, M.: Influence of Intermetallic Phases on the Fracture Surfaces in Secondary Aluminium Cast Alloy. Acta Metallurgica Slovaca - Conference, vol. 3, 2013, 65-74. ISSN 1338-1156.

[4] BRUNA, M., KUCHARCIK, L., SLADEK, A.: Complex Evaluation of Porosity in A356 Aluminium Alloy using Advanced Porosity Module. Manufacturing Technology, vol. 13, No.1, 2013, 26-30. ISSN 1213-2489

[5] TAYLOR, J.A.: Iron-containing Intermetallic Phases in Al-Si Based Casting Alloys. Procedia Materials Science, vol. 1, 2012, 19-33. ISSN 2211-8128.

[6] JI, S., et al: Effect of Iron on the Microstructure and Mechanical Property of Al-Mg-Si-Mn and Al-Mg-Si Die Cast Alloys. Materials Science \& Engineering A, vol. 564, 2013, 130-139. ISSN 0921-5093.

[7] TILloVA, E., CHAluPOVA, M., HURTAlOVA, L.: Evolution of Phases in a Recycled Al-Si Cast Alloy during Solution Treatment. Scanning Electron Microscopy, InTech: Croatia, 2012, 412-438. ISBN 978-953-51-0092-8

[8] CAO, X., CAMPBELL, J.: Morphology of $\mathrm{Al}_{5} \mathrm{FeSi}$ Phase in Al-Si Cast Alloys. Materials Transactions, vol. 47, No. 5, 2006, 13031312. ISSN 1347-5320.

[9] ZHU, S. et al: Influences of Nickel and Vanadium Impurities on Microstructure of Aluminum Alloys. JOM, vol. 65, No. 5, 2013, 584-592. ISSN 1543-1851.

[10] PETRIK, J., HORVATH, M.: The Iron Correctors in Al-Si Alloys. Annals of Faculty Engineering Hunedoara - Intern. J. of Engineering, 2011, 401-405. ISSN 1584-2673.

[11] ZIHALOVA, M., BOLIBRUCHOVA, D.: Possibilities of Iron Elimination in Aluminium Alloys by Vanadium. Manufacturing Technology, vol. 13, No. 3, 2013, 289-296. ISSN 1213-2489

[12] GUSTAFSSON, G., THORVALDSSON, T., DUNLOP, G.L.: The Influence of Fe and $\mathrm{Cr}$ on the Microstructure of Cast Al-Si-Mg Alloys. Metallurgical Transactions A, vol. 17A, 1986, pp. 45-52. ISSN 1543-1940.

[13] BOlibruchovA, D., RICHTATECH, L., ORLOWICZ, W.: Possibilities of Eliminating the Higher Amount of Iron in Secondary AlSi7Mg0.3 Alloy by Chrome. Communications - Scientific Letters of the University of Zilina, vol. 16, No. 3A, 2014, 119123. ISSN 1335-4205.

[14] TILLOVA, E., CHALUPOVA, M.: Structural Analysis of Al-Si Alloys (in Slovak). EDIS ZU : Zilina, 2009, 191 p. ISBN 978-80-5540088-4

[15] HONZATKO, R., MICHNA, S., CAIS, J.: The Influence of Porosity on Mechanical Properties of Casts Produced from Al - Si Alloys. Manufacturing Technology, vol. 13, No. 3, 2013, 289-296. ISSN 1213-2489

[16] NOVOTNY, J., CAIS, J., NAPRSTKOVA, N.: Analysis of Aluminium Alloys AlSi7Mg0.3 and AlMg3 by Means of X-Ray Diffraction. Manufacturing Technology, vol. 14, No. 3, 2014, 392-397. ISSN 1213-2489. 